teoria polityki 5 | 2021 s. 7-12

\title{
Między biologią a polityką - pytania, dylematy, interpretacje
}

Tematem wiodącym numeru czasopisma „Teoria Polityki” w 2021 roku jest biologia i polityka. Na ironię zakrawa fakt, że natura, która zgodnie z pozytywistycznym paradygmatem (jak nam się wydawało) została zepchnięta w znacznym stopniu przez postęp cywilizacyjny poza sferę naszej zachodnioeuropejskiej świadomości, wraca tylnymi drzwiami, przypominając, że to ona jest ostateczną instancją. Jak widzimy na przykładzie COVID-19, ten na pierwszy rzut oka truizm dotyczy zarówno sfery polityki, stosunków społecznych, relacji międzynarodowych, jak i kształtowania procesów ekonomicznych. Biologiczna konieczność, o której zdążyliśmy zapomnieć, obudowując ją techniką i kulturą, wraca ze zdwojoną siłą w starej formie (choroby zakaźnej), ale w nowym otoczeniu (neoliberalizm).

W sferze polityki wydaje się, że COVID-19 uderzył głównie w zwolenników zminimalizowania roli państwa. Gdyby nie działania państwa, rezultaty, do jakich prowadzi pandemia $\mathrm{w}$ sferze ekonomicznej i zdrowotnej, byłyby dużo bardziej dotkliwe. Czy może to oznaczać powrót do Keynesowskich koncepcji ekonomicznych i budowy ładu społeczno-politycznego wokół nowego państwa dobrobytu?

Pytanie pozostaje otwarte. Wydaje się jednak pewnym przeformułowanie przynajmniej części kwestii technicznych związanych z dyskursem politycznym. Ograniczenia pandemiczne pozwoliły na przekroczenie bariery komunikacyjnej i przejście $\mathrm{z}$ formy face to face na elektroniczną. W wielu instytucjach procesy związane $\mathrm{z}$ wyborami i głosowaniami są prowadzone przy użyciu sieci komputerowych. Bliski obywatelom problem dostępu do administracji publicznej został przynajmniej w niektórych przypadkach rozwiązany poprzez możliwość realizacji części zadań online. Pewne implikacje dla sfery politycznej przynosi rozrastający się sektor pracy zdalnej. Jeżeli taka forma pracy utrzyma się przynajmniej w części aktualnej skali, konieczne będzie wprowadzenie nowych rozwiązań prawnych, co może generować nowe pole konfliktu między istotnymi podmiotami życia politycznego, np. partiami, organizacjami pracodawców i związkami zawodowymi. 
Odrębny problem dotyczy tego, na ile jako jednostki i społeczeństwo jesteśmy nieustannie skonfrontowani z całą, obcą nam i zagrażającą sferą przyrody i biologii, a na ile udało nam się poprzez zdobycze naukowe od niej uciec. W tym rozumieniu pandemia może być tylko swoistym wypadkiem przy pracy, które od czasu do czasu się zdarzają i będą się zdarzać. Można przyjąć również przeciwną narrację i sytuować człowieka jako przede wszystkim część porządku natury, w którego przypadku próby wyłamania się z naturalnego porządku skutkują ostatecznie katastrofami (np. globalne ocieplenie).

Jeszcze inne podejście, redukujące człowieka do jego funkcji biologicznych, prezentował Edward O. Wilson, według którego „samoświadomość jest kształtowana i kontrolowana przez ośrodki emocjonalne mózgu, zlokalizowane w podwzgórzu i w obrębie układu limbicznego. Wszystkie emocje docierające do naszej świadomości - nienawiść, miłość, poczucie winy, gniew i inne - wypływają właśnie z tych ośrodków” (Wilson, 2000, s. 15). Co więcej, „ujmując rzecz po darwinowsku, można powiedzieć, że organizm nie żyje dla siebie. Jego podstawową funkcją nie jest nawet wytwarzanie kolejnych organizmów, on jedynie reprodukuje geny i służy jako ich tymczasowy nośnik" (Wilson, 2000, s. 15). Wilsonowska socjobiologia, otwierając perspektywy rozumienia pewnych obszarów życia, zamykała inne. Co jednak ważniejsze, wydaje się ona trudna do przyjęcia dla części badaczy ze względu na radykalne odcięcie się od rozumienia kulturowych wytworów człowieka jako głównej albo przynajmniej autonomicznej podstawy konstruowania świata społecznego.

Być może właśnie $\mathrm{z}$ tego powodu badania sytuujące się na pograniczu biologii i polityki nie były i nie są często podejmowane. Zdecydowana większość politologów przyjmuje klasyczne rozumienie polityki, tzn. jako rządzenie państwem, sztukę sprawowania władzy, mechanizmy działania instytucji, realizację dobra wspólnego itp. Prowadzi to do sytuacji przeciwnej, tzn. całkowitego albo prawie całkowitego usunięcia czynnika biologicznego z rozważań przedstawicieli nauk o polityce.

Artykuły zawarte w poniższym tomie stanowią próbę powiązania dwóch pozornie odległych od siebie obszarów, co - jak się wydaje - przynajmniej w części się udało. Autorzy rozmaicie spoglądali na analizowane związki, zarówno ze względu na odmienne stanowiska teoretyczne, stosowane metody, jak i przedmiot swoich badań. Jedyne, co pozostaje dla wszystkich wspólne, to usytuowanie na polach badawczych, zakreślonych przez szeroko ujęte zależności zachodzące pomiędzy biologiczną i polityczną sferą życia społecznego. Problematyka ta ma stosunkowo bogatą tradycję i niemały dorobek badawczy w różnych dyscyplinach i dziedzinach naukowych. Jest eksplorowana i popularyzowana nie tylko przez pryzmat biologicznych determinant i uwarunkowań decyzji czy zachowań politycznych, ale także w kontekście takich zagadnień jak wpływ zmian klimatu na procesy migracyjne, wyczerpywanie zasobów naturalnych a kierunki współczesnej geopolityki czy skutki działań i strategii 
politycznych w procesach ewolucji. Jednak obecnie, w okresie światowego zagrożenia pandemicznego związanego z ekspansją nowego koronawirusa, tematyka ta nabiera nowego, niezwykle aktualnego znaczenia. Uwidacznia bowiem, jak bardzo sfera polityki, bezpieczeństwa i gospodarki jest skorelowana ze światem medycyny, przyrody i natury, a zarazem jak obie te sfery potrafią wzajemnie na siebie oddziaływać. Zamieszczone w niniejszym numerze czasopisma teksty eksplorują tę sferę $\mathrm{w}$ trzech węzłowych perspektywach. $Z$ jednej strony podejmowane zagadnienia są związane $\mathrm{z}$ interpretacją polityki w perspektywie założeń współczesnych koncepcji neoewolucjonistycznych. Odmienną perspektywę prezentują autorzy eksplorujący tematykę biopolityki, czyli sferę zależności, jaka tworzy się między skutkami decyzji, działań i procesów politycznych a procesem ewolucji społecznej. Jeszcze inne spojrzenia na tematykę tomu zawierają teksty charakteryzujące relacje między polityką a szeroko rozumianym środowiskiem naturalnym.

Richard W. Bloom w swoim tekście odnosi się do związków między biologią a polityką w kontekście filozofii nauki, sięgając do tradycji filozoficznych od czasów starożytnych aż po współczesność. Autor na pograniczu dwóch obszarów sytuuje psychologiczną ciemną tetradę, tj. narcyzm, psychopatię, machiawelizm i sadyzm, które wpływają na kształtowanie się sfery politycznej oraz działań indywidualnych podmiotów życia w polis. Opierając się na współczesnych zjawiskach w sferze stosunków wewnętrznych i międzynarodowych, rysuje perspektywę, w której (jakkolwiek literacko to zabrzmi) „ciemność może być naszym przeznaczeniem".

Próbę szerokiego spojrzenia na możliwe przesłanki wykorzystania badań socjobiologów w politologii podejmuje Jarosław Nocoń przy założeniu odrzucenia najbardziej radykalnych form determinizmu przyrodniczego. Zdaniem autora zarysowana przez socjobiologów perspektywa teoretyczno-metodologiczna może okazać się przydatna na wielu polach w naukach o polityce, m.in. przy badaniu podmiotowości politycznej państwa, form organizacji, sposobów agregacji i reprezentacji interesów wspólnoty. Należy jednak podkreślić, że próba wprowadzania wyjaśnień biologicznych nie oznacza całkowitego usunięcia przyczyn kulturowych, a jedynie ich wzajemne uzupełnienie.

Kolejny artykuł, Neuropolityka - geneza, założenia, perspektywy rozwoju, zawiera bardziej optymistyczne wnioski. Autorzy, Piotr Rutkowski i Jacek Ziółkowski, wskazują na odrzucenie kartezjańskiego dualizmu jako podstawy neuronauk i uwzględnienia badań zarówno „o charakterze biologicznym, jak i (...) czynników społeczno-kulturowych" w celu pełnego poznania człowieka. Takie rozumienie związków kultury i biologii już na pierwszy rzut oka różni się od przyrodniczego determinizmu, stając się w jakimś stopniu stanowiskiem pośrednim i alternatywą dla jednostronnych interpretacji rzeczywistości. Wydaje się, że nowa perspektywa badawcza może przynieść znaczne korzyści na polu lepszego zrozumienia człowieka i jego działalności politycznej, ale także 
w naukach politycznych - otwierając nowe pola badawcze i rysując nieznane dotychczas modele eksplanacyjne.

Piotr Łukomski swoją analizę w artykule Problem kategorii decyzji w kontekście naturalistycznego paradygmatu nauk społecznych opiera na akcie wyboru, interpretowanym w ramach teorii kontroli pozwalającej na osadzenie decyzji w ramach posiadanych informacji i ich przetwarzania. Autor otwiera w ten sposób pole do rozważań nad wolnością, autonomią jednostki, tożsamością indywidualną i ich związkiem $\mathrm{z}$ kształtowaniem ładu politycznego.

Przemoc jako zjawisko ściśle związane z polityką traktuje Kornel Bielawski. W artykule dotyczącym naturalizacji przemocy szeroko rekonstruuje dyskurs dotyczący jej źródeł na podstawie myśli filozoficznej, dyskursu akademickiego, praktyki społecznej i politycznej. Co istotne, zachowania przemocowe nie zawsze traktowane są jako destrukcyjne dla jednostki czy grupy. Zdarza się, że w przyrodzie przemoc „stanowi (...) element równowagi i charakteryzuje się pewnym znaczeniem budującym relacje wewnątrzgrupowe, czy to dotyczące hierarchii, dominacji, czy kształtowania zachowań pożądanych przez grupę". Ważne jednak, aby „skala zniszczeń wynikających z przemocy” nie przewyższała „zdolności do podtrzymania związków i korzyści z nich płynących”, ponieważ może to doprowadzić do „dezintegracji związku lub grupy”.

Do biologii jako podstawy bezpośrednich technik wpływu politycznego odwołuje się Adam Hołub, omawiając środki stosowane przez bioterrorystów. Autor odnosi się do historycznych przykładów ataków terrorystycznych, dotychczasowych klasyfikacji metod i środków, usytuowania w prawie krajowym i międzynarodowym. Wydaje się, że przybliżane w tekście bezpośrednie metody destrukcji fizycznej w największym stopniu unaoczniają zagrożenia, jakie niesie ze sobą lekceważenie wpływu natury na obszar społeczno-kulturowy.

Konsekwencjami, jakie niesie wdrażanie w życie paradygmatu neoliberalnego, zajął się Janusz Golinowski. Autor proponuje spojrzenie na współczesny system polityczny przy założeniu, że jest on kształtowany w „następstwie sprzężenia nowych technologii i rozwoju gospodarczego $\mathrm{z}$ marginalnym szacunkiem dla prywatności i zaborczością neoliberalnego państwa”. Krytyczne spojrzenie na relacje władzy, polityki i biologii ogniskuje się w rekonstruowanych w artykule poglądach Michela Foucaulta, który jako chyba największy współczesny demaskator ukrytych struktur odnajdywał w na pozór niewinnych praktykach próby zdominowania i zniewolenia człowieka. Z taką dominacją mamy do czynienia współcześnie, kiedy „neoliberalizm zmarginalizował sieci bezpieczeństwa społecznego, systemy opieki zdrowotnej oraz inne elementy infrastruktury wspierające ludzkie życie. Jednocześnie neoliberalne reżimy we wszystkich skalach rozpieszczały i wspierały pakiety kapitału korporacyjnego w różnych formach". Pandemia COVID-19 unaoczniła jednak, że dotychczasowa formuła się wyczerpała i należy szukać nowych rozwiązań strukturalnych. 
Z podobnych pozycji teoretycznych wychodzą Sławomir Czapnik i Ineza Drewniak. W przypadku ich artykułu również wskazywanym podłożem dla kształtowania aktualnego ładu biopolitycznego jest neoliberalizm jako system opresyjny, którego rozumienie ułatwia myśl Foucaulta oraz koncepcje marksistowskie. Według autorów praktyczną ilustracją dla teoretycznych rozważań mogą stać się współczesne polskie reality shows. Wnioski, jakie płyną z analizy, są jednoznaczne: „Kobiece ciała w rodzimych reality shows są poddane neoliberalnej biowładzy, dyscyplinowane i samodyscyplinujące się", a także poddane „uciskowi patriarchatu” i „wyzyskowi klasowemu”.

Przemysław Maj przenosi analizę do sfery programów i ideologii politycznych, konfrontując ze sobą problem ochrony środowiska i jego rozumienie wśród przedstawicieli szeroko rozumianej lewicy i prawicy w kontekście reprezentowanych przez nich metawartości. Autor wskazuje, że osoby o poglądach prawicowych będą uznawały, że „to człowiek dominuje nad światem przyrody - co jest wypadkową akceptacji metawartości: religia, władza i nierówność". Oznacza to, że będą preferowały wzrost gospodarczy kosztem jego negatywnych skutków dla środowiska naturalnego. W ramach poglądów lewicowych nacisk kładziony jest na relacje człowiek - przyroda, a podstawą są takie wartości jak równość, progresywizm i racjonalizm. W takim rozumieniu jednostka ludzka „jest częścią przyrody - jednym $\mathrm{z}$ jej równorzędnych elementów”. Zarysowane w ten sposób podziały zdają się mieć swoje uzasadnienie w rzeczywistości i praktyce politycznej, do której odnosi się autor artykułu.

Od problemu dualizmu podmiotu rozumianego jako podział na ciało i duszę wychodzi Sonia Horonziak, rekapitulując podstawowe założenia myśli Arnolda Gehlena. Niemiecki filozof ostatecznie zniósł kartezjański dualizm poprzez kategorię czynu, w którym łączy się to, co fizyczne, i to, co duchowe. Istotne jest również to, że zdaniem Gehlena człowiek naznaczony jest brakiem, który powoduje konieczność opieki nad nim przez instytucje państwowe, będące w dużym stopniu wytworem kultury uzupełniającej to, co biologiczne. W pewnym sensie dopiero takie połączenie potrzeby i instytucji jako biologii i kultury pozwala na pełne rozumienie człowieka jako istoty społecznej. Takie rozumienie skierowało Gehlena na skrajnie konserwatywne pozycje obrony instytucji, które po II wojnie światowej były szeroko krytykowane.

Praktycznych związków polityki i biologii dotyczy artykuł The Role of a Medicalized Discourse in the Global Activities of the World Health Organization. Autorka omawia w nim zdrowotne programy WHO, dotyczące tytoniu i starzenia się, które realnie wpływają na życie mieszkańców globu. Przeniesienie poziomu rozważań z poziomu teoretycznego (z jakim mamy do czynienia w większości pozostałych artykułów) na praktykę pozwala uświadomić sobie utylitarny charakter, jaki może rysować się na styku dwóch analizowanych obszarów.

W ostatnim artykule Alvydas Jokubaitis podjął rozważania na temat tekstu Epilog Leo Straussa. Według Jokubaitisa tytułowy tekst sprawia wrażenie 
niedomkniętego. Znajdujemy w nim rozróżnienie dwóch podejść do polityki, naukowego i filozoficznego. Współcześni politolodzy, funkcjonując $\mathrm{w}$ ramach paradygmatu pozytywistycznego, odrzucają namysł filozoficzny nad polityką, co stawia ich na przegranej pozycji wobec prób pełnego zrozumienia rzeczywistości społecznej, którego nie można dokonać bez odniesienia się do pojęć pierwotnych. Sam Strauss rozumiał politologię jako filozofię polityczną i wydaje się, że przynajmniej częściowa refleksja nad takim jej rozumieniem mogłaby przynieść korzyść reprezentantom tej dyscypliny.

Dominik Bień

\section{Literatura}

Wilson, E.O. (2000). Socjobiologia: wydanie popularnonaukowe. Poznań: Zysk i S-ka. 